\title{
The Influence of Indian Literary-Philosophical and Religious Works on the Eastern Literature
}

\section{Besire Azizaliyeva}

Assoc.Prof. The Institute of Literature named after Nizami of the ANAS, Baku, Azerbaijan

\begin{abstract}
The religious and philosophical elements expressed in ancient Indian literature have had great influences on world literature. One notable example is the ancient Indian piece, "Panchatantra". This magnificent written work ofworld literature has become one of the most famous and influential works in the development of the European and Asian story genre. The Indian masterpiece has also influenced the Arabic-American immigration writer, Kahlil Gibran. Thus, the impress of Indian scripturecan be seen in many of Gibran's works such as "The Prophet". The philosophical and religious teachings of the "Bhagavad Gita" have had an impactful role in M. Naimy's development as an Arabic immigration writer. Mikhail Naimy, a poet, writer and a literary critic, was one of the prominent representatives of the early $21^{\text {st }}$ century Arab-American immigrant literature. When conveying the idea of wholeness and unity between an individual soul and God in his work, "The Book of Mirdad", the author used different religious and philosophical sources including the ancient Indian scripture Bhagavat-Gita. The concepts such as an eternal soul, "I", a God's messenger are very similar in "The Book of Mirdad" and the Indian religious-philosophical teachings. M.Naimy has accented the importance of issues that reflect many of the ancient Indian beliefs expressed in the "Bhagavad Gita" including the material sides of world and divinity, vision, soul, and spirit. The ancient Indian beliefs of "The People are Raised to the God's level" are distinctively reflected by M. Naimy in his novel "The Book of Mirdad".
\end{abstract}

Keywords: Mikhail Naimy, "The Book of Mirdad", Bhagavat-Gita, God,

\section{Introduction}

Being ancient and rich enough, Indian literature, literary-philosophical views and ancient Indian beliefs have impacted world literature in a variety of ways throughout history that Eastern and Western men of letters benefited from those sources to a great extent. Indian sources have widely spread and influenced world literature in Eastern and Western aspects. Literal works and philosophical sources of the Eastern world, particularly, nations of the Near East, Turkish, Arab and othersincomparably paved the ways for Indian sources to come into prominence over the whole globe. First and foremost, ancient Indian collection of fables, proverbs, anectodes, stories - "Panchatantra" which dates back to the $3^{\text {rd }}-4^{\text {th }}$ centuries significantly influenced the Eastern and Western literature with its didactic nature. This magnificent piece turned into one of the most well-known works having led to bring about profound effects on the development of European and Asian story genre. "Pachatantra", however, was translated into the Arabic during the reign of Khosrow Anushiravan I, the celebrated leader of The Sasanian Empire (Iran), unfortunately, it failed to survive until now. As soon as the Indian masterpiece was translated into the Arabic in the mid-8th century, it immediately affected the way Near Eastern literature developed, obviously, formed the rich basis for literal thought and genre. Afterwards, Abdullah Ibn al Muqaffa skilfully supplemented the missing parts and completed the work with its Arabic translation- "Khalilah wa Dimnah". Being not only a translation, but with a variety of genres and amazing essence reflecting Indian spirit, it eventually took its unprecedental place in world literature. Additionally, "Pachatantra" was translated into more than 60 European and Asian languages over 200 times $^{1}$. In this regard, the splendid Indian literal piece of art impressed Azerbaijani literature as well as vast majority ofthe Eastern people - Turkish, Arab, Persian and others.

1Гринцер, П.А. (1984). Классическая древноиндейская литература. История всемирной литературы, II т., М., Наука, /26$66 /, 41$. 
On the other hand, Indian resources gained popularity in the West through the writers travelled to India and settled down there in recent centuries of the world civilization.

As the classical heritage was enthusiasticallystudied and new attitudes were getting shaped towards culture in the 20th century, Indian literature and religious-philosophical views aroused a striking interest again in this period. Furthermore, well-known writers of Arab immigration literature welcomed the Indian literal contributions in their works, specifically those who lived in the USA, Gibran Kahlil Gibran and Mikhail Naimy. While both Christian writers adroitly took advantage of religious elements in Islam, Christianity, Sufism philosophical teachings, Eastern and Western literature and philosophy schools, they worked up original themes, transformed ideas, created up-to-date motives based on ancient Indian literature and religious-philosophical thoughts. It is important to note that aforementioned authors did not simply referred to certain Indian sources in their works, rather they tended to use the synthesis of those elements ingeniously. Namely, they pointed to the nuances that were of different sources but the same perception in the similar way where religions, philosphical views, cultures have a lot in common in terms of congruent concepts. Yet, some comparable ideas in "The Prophet", "Words of Gibran" by G.K.Gibran were derived from "Khalilah wa Dimnah", M. Naimy accented the importance of issues that reflected many of the ancient Indian beliefs expressed in the "Bhagavad Gita" and combined delicately with the thoughts originated from Sufism. This article elaborately focuses on the aspects correlating with Indian beliefs in M.Naimy's novel "The Book of Mirdad".

\section{M.Naimy as one of famous Arab immigration writers}

Mikhail Naimy, a poet, writer and a literary critic, was one of the prominent representatives of the early $21^{\text {st }}$ century ArabAmerican immigrant literature. Arab immigration literature which is commonly known as "An Nahda" - the renaissance period"1 in Arab literature has brought quite new trends to the well-rooted and rich Arabian culture. Apparently, Arab immigration literature has been formed on the literary traditions of the new stage - $19^{\text {th }}$ century Arab literature absorbing its own national background and global literary-philosophical tendency. M.Naimy, the philosopher and writer made practical use of various philosophical heritages and cultures of the both Eastern and Western world and illustrated them in his literary creation in a unique manner. "The Book of Mirdad" (1946) is of great importance in M.Naimy's literary legacy written in English, as well. M.Naimy has highlighted the significance of issues that mirror the material sides of the world and divinity, vision, soul and spirit. Within the framework of these issues, M.Naimy also cited several religious, religious-philosophical and philosophical teachings in one of those crucial scriptures - "Bhagavad Gita" in which most of ancient Indian beliefs were written down.

\section{Similarities between "The Book of Mirdad" and "Bhagavad Gita"}

"Bhagavad Gita", one part of "Mahabharata" was composed 5000 years ago based on the dialogue between God and Lord Krishna's companion and bouncer Arjuna in the Sanskrit language. Today, it is widely admitted as a set of philosophical and religious teachings which inspires people to reach the utmost spiritual level of perfectness. Undoubtedly, the philosophical and religious influence of "Bhagavad Gita" can clearly be seen in M.Naimy's literary works. As for the both the ancient Indian beliefs and M.Naimy's outlook, the common characteristic is the idea of "lifting the people up to the God's level"2.

\section{a) The "Prophet" concept}

In the chapter "The Bound Abbot" of the book, there at the top of As and Lebanon mountains, at the Altar Peak remains the wreck of Ark dating back to Noah's time based on a legend. According to the legend, when dying prophet Noah, in his last will and testament he ordered to build the Ark and bid his son Sam and "nine chosen people" : "I bid you, my son, to build an altar upon the highest peak in these mountains, which peak shall henceforth be known as Altar Peak. Upon that altar I propose to offer my last thanks offering. And from the fire I shall kindle thereon I bid you keep a light perpetually burning. As to the house, you shall make of it a sanctuary for a small community of chosen men whose number shall never exceed nine, nor ever be less than nine. They shall be known as Ark Companions. They shall not leave the sanctuary, but shall be cloistered therein all their days, practicing all the austerities of the Mother Ark, keeping the fire of faith burning and

\footnotetext{
1 İmanquliyeva, A. (2003). Yeni ərəb ədəbiyyatı korifeyləri, Bakı, Elm, 13.

2 Güngören, 1. (1981). Buda ve öğretisi, Ankara, Yol yayınları, 42.
} 
calling unto The Highest for guidance to themselves and to their fellow-men."1 There were 8 people in the Ark, the last one to be the 9th in the community was Mirdad who was depicted as a messenger representing "I" concept in close relation to "Bhagavad Gita" as a figure of God and as for M. Naimy the one conveying prophet ideology. Likewise, for the orientalist A.Imanguliyeva, Mirdad bears a striking resemblance with a prophet owning a perfect character more than a simple person might have. In the novel Noah talks Sam about the 9th man in the Ark: "Behold, I revealed unto you a great secret, my son. The ninth person was a stowaway, known and seen by me alone. He was my constant companion and my helmsman. Ask me no more of him, but fail not to make room for him in your sanctuary. These are my wishes, Sam, my son. See you to

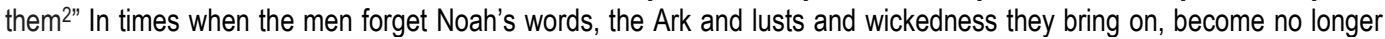
mindful about the Faith, Mirdad arrives in the long run. Certainly, the motives involving "when mankind are no more mindful of faith, prophets come back" are as vivid as they are in Islam, Christianity and ancient Indian beliefs. "We were already swallowed down by the female lion of ignorance, whereas, God's mercy for the living for especially men is infinite. So, for that reason He chose His companion Arjuna as His apprentice and recited Bhagavad Gita. As being the companion of God, Arjuna stood out above the ignorance in all ways. However, he was left in such a desperate situation in Kurukshetra battlefield that he would shed light on the daily problems when people asked Krishna. Thus, having gone through these, God wanted men to ask Krishna for solutions and Arjuna to be obliged to clear them up for favor of next generations." ${ }^{3}$

"Bhagavad Gita" assures that getting in touch with those who sethigh and moral integrity like Krishna and revealing the secret about God are as necessary as "listening to God himself." In the same way, Mirdad, in the novel by M.Naimy, is the central character undertaking the mission - to tell the secret of God to the people when they ended up losing divine love and became worldly-minded. Moreover, the stranger with pathetic appearance, "famished and covered with wounds" asks to join the community centuries after Noah's death and who takes the control of the Ark's wheel - Mirdad resembles rebirth of soul in ancient Indian beliefs. It is stated in the "Bhagavad Gita" (Chapter 4, Text 5): "God, The Almighty, said: "O man

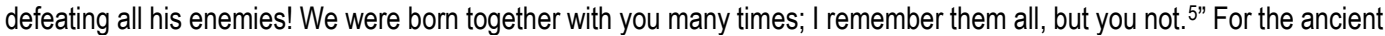
Indian piece of art, the soul reincarnates in various bodies as it undergoes a 3-stage-development consisting childhood, adolescence and senescence in body everlastingly 6 .

\section{b) "I" concept}

M.Naimy believes the word "I" is a perfect word: "To feel Himself; to think Himself; to speak Himself God need not utter more than I. Therefore, is I His only word. Therefore, is it THE WORD."

M.Naimy doesn't mean lexicalperfectness of the word in a sentence as a method conveying the idea, but the word "I" is perfect mainly because it conveys the meaning of God: "For understanding is the Spirit Holy that vivifies the Word, and binds it unto Consciousness. It is the rider-beam of the balance Eternal whose two pans are the Primal Consciousness and the Word8."

The Arabian writer, therefore, considers human self as the manifestation of God's self and as a bearer of the holy spirit. In Naimy's view, "I" itself is both creative and creature, from this perspective, he reasons existence of the spiritual bond

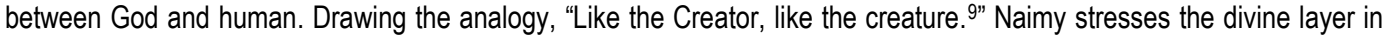
the human spirit. He points the fact out that human beings are inclined to aspire for ephemeral, worldly things with their egos, on the other hand: "Many satans exsist there in the world you live, you yourselves have created them ${ }^{10}$." "I" is the core of everything in your world and source of everything you own in your life. As long as the core is sustained, your world will be sustained. Anyhing under the sun, nor in the heavens is able to destroy your harmony. But when it appears today

\footnotetext{
${ }^{1}$ Naimy, M. (1993). The book of Mirdad, New York, Arkana penguin books, 10.

2 Naimy, M. (1993). The book of Mirdad, New York, Arkana penguin books, 10.

${ }^{3}$ Bhaqavad-qita olduğu kimi. (1991). Bhaktivedanta Buk Trast, 24.

4 İbid, 219.

5 İbid, 201.

6 İbid, 94.

${ }^{7}$ Naimy, M. (1993). The book of Mirdad, New York, Arkana penguin books, 41.

8 İid, 41.

9 İbid, 296.

10 Naimy, M. (1993). The book of Mirdad, New York, Arkana penguin books, 296.
} 
here, tomorrow there and the other day in another place, then your world is doomed to collapse sooner or later. "' M.Naimy heeds the significance of constant and perfect faith and previses the men to be aware of the feeble sidesof human ego. In like manner, it is noted in "Bhagavad Gita" (Chapter 8, Text 7): "You definitely will reach me dedicating your whole self, life and cognition to Me."

Arabian writer indicates the necessity of having an absolute understanding which denotes the spiritual ties between God and manifestation of God in what he created. "God knows with His Conscious that everything He created is the Whole ${ }^{3 "}$. Naimy thinks of God - "l", as being immortal and eternal, nevertheless, for man he mentions the shortcomings of his "I" giving the example of a particle and the Whole. Because, he is weak and incapable as engulfed in "birth and death" 4 "Remember that the Word is one. And you, as syllables in The Word, are in reality but one. ${ }^{5}$. In the old Indian scripture, "Bhagavad Gita" (Chapter 2, Text 6) the same opinions were clearly mentioned: "Saints achieve eternal peace and perfectness indeed who are those can see the God deeper inside and outside of everything. 6" In the same book, (Chapter 9, "The Most Confidential Knowledge", Text 6) the unity between God and man is describeddistinctively: "Like the mighty wind always in the world, indeed, all the living things are inside Me."

M.Naimy believes that struggling with one's ego and triumphing over it is the only way to preserve the unity with "l" and pay respect to God's spirit. Getting rid of material handicaps "I" of man gets the opportunity to become one in God's. "Throw the swaddles away which swaddle your "l" and only then you will be able to see the Word akin to His, the Word that everything got the origin from it and only then you will see everything in harmony and peace within one syllable. 8 " "Bhagavad Gita" (Chapter 2,"Gita's Summary", Text 55) explains the method of reaching perfect identity by leaving material pleasure of man's ego: "God, the Almighty said: "O Partha, whenever man clears the indulgence outfabricated by mind, his mind becomes clear. And he takes the first step to be pleased in his self, now, he is in the pure transcendental consciousness. ${ }^{9 "}$ "Bhagavad Gita" presents the idea of perfectness in man's personality who never adheres to good or bad things; neither aspires for them nor hates them. The man succeeding this independence of self refers to the state of person who has already reached the perfect knowledge. ${ }^{10}$

The arrival of Mirdad aimes to restore the deranged divine balance between God and man as all the prophets were assigned to. However, Naimy's Mirdad has one more peculiar mission besides teaching people their responsibilities and delivering God's words. It is to "represent God in man"11.

Naimy's fundamental "I" concept is mainly expressed in these thoughts. Arab writer regards man as "bearer of the world in his "l" who is the greatest reflection of God.When Naimy says "When with men, I am a god. When with God, I am a man."12

In "The Book of Mirdad" he gives vent to his own opinions of "l" concept where he presents his views certainly about God not he means "man is a god." Naimy asserts "I", "Word" and "Consciousness" is the trinity of being and he calls it "the perfect balance". He says that but people name this balance - "God". As the burden of word is inside the meaning of it, Naimy takes to deliver the faith to the existence of nonmaterial and invisible Godupon himself. Thus, he puts the sacred

\footnotetext{
${ }^{1}$ Naimy, M. (1993). The book of Mirdad, New York, Arkana penguin books.

2 Bhaqavad-qita olduğu kimi. (1991). Bhaktivedanta Buk Trast, 366.

${ }^{3}$ Naimy, M. (1993). The book of Mirdad. New York, Arkana penguin books, 45.

4 İbid, 46.

5 libid, 47.

${ }^{6}$ Bhaqavad-qita olduğu kimi. (1991). Bhaktivedanta Buk Trast, 92.

7 İbid, 398.

${ }^{8}$ Naimy, M. (1993). The book of Mirdad. New York, Arkana penguin books, 307.

${ }^{9}$ Bhaqavad-qita olduğu kimi. (1991). Bhaktivedanta Buk Trast, 137.

10 İbid, 138.

${ }^{11}$ Naimy, M. (1993). The book of Mirdad. New York, Arkana penguin books, 52.

12 libid, 50.
} 
essence of words to use and explains the sincerity and perfectness of them in this regard. With his own method, Naimy demonstrates his faith to God's existence: "God is a holy name. Thus, thoughts he made holy are holy. So what if man is not a manifastation of God? Then of whose it would be? May be man is diferent from God itself? Does not a whole wood hide in the oak? Does not God spread around and embrace the soul of man?"

Common aspects of Naimy's thoughts in Mirdad's words "When with men, I am a god. When with God, I am a man."1 with "Bhagavad Gita" (Chapter 4, "Transcendental Knowledge",Text 7) are uttered: "Son of Bhatra! Whenever the religion falls down, wickedness emerges, then I appear." In the statement, God is supposed to appear with His own nature mirroring man when people neglect the faith. Like Mirdad's role in the novel holding the wheel of Noah's Ark during the Flood and his arrival after many years is closely linked with the ideas in the religious-philosophical teaching.

\section{c) "God" concept}

M. Naimy shows monotheism forth: "God is not many. God is one. But many and divers are yet men's shadows. So long as men cast shadows on the earth, so long is each man's god no greater than his shadow. The shadow-less only are all in the light. The shadow-less only know one god. For god is Light, and Light alone is able to know Light."

M. Naimy thinks man is a being who shades the earth but under a borrowed light of himself. But those who harbor God's light within their hearts, they will be enlightened by God's light shaking off the shades. Hence, shades symbolize the material world's manacles and represent the controversy among those "clung in their shades" and "glimmering with understanding". ${ }^{4}$ So, Mirdad intends to agglomerate the shades and free the people from the world's cage and help them to realize their enlightenment with their divine lights. In Naimy's views, it is the sole way to cognize the reality: "As the Light of God beams over you, then all the secrets will seem you with its ins and outs with no need of evidence."5

Mirdad was represented as a man bearer of the God's light. He is the chosen one who already freed from the "shell" of the material world. ${ }^{6}$ Therefore, differs from others "When with men, I am a god. When with God, I am a man."7 Naimy, like it is the same as in other religions and religious-philosophical teachings supports the idea of the unity of all things and God, togetherness of the particle and the Whole:"What name can ever designate a Man who is no longer 'in the shell'? What country can contain a Man in whom a universe is contained? What ancestry can claim a Man whose only ancestor is God? ${ }^{8}$ . All these words clarify Naimy's sense of God and the mission of Mirdad.

Monotheism perception like other heavenly religions is the subject matter for "Bhagavad Gita". Despite the fact that there are still controversies whether it is so or not, the texts of the olden scripture confirm the truth about its monotheistic character. "To worship other goddesses or serve them is not lawful." Another fact reaffirms it: "Of whose cognizances were stolen by worldly wishes devote themselves to goddesses and practice rituals conforming to their nature." (Chapter 7, Verse 20) It directly refers to the idea that the people who are under captivity of their passions, they praise not Krishna but other goddesses...Krishna is the greatest satisfaction and in the holy book, it is said that God is the source of all satisfaction or its treasure." In the novel, Mirdad speaks on Naimy's behalf implying that "There are not gods, but there are gods that worldly-minded people themselves made them up.": "Shades of man are various. As long as man casts a shadow over the earth, his God will step parallel to his shade."

In Naimy's interpretation of man-God relations, it is openly understood that the views writer referred to man's dedication to God, came from "Bhagavad Gita". The ancient Indian belief promotes to serve God with transcendental love and leave the earth-born ambitions and likings. "Dhananjaya! Serve God faithfully, stay away from hideous acts. They are ungenerous who are delighted with the outcomes of what they have done." (Chapter 2, Text 49) ${ }^{10}$ According to the ancient Indian beliefs,

\footnotetext{
${ }^{1}$ Naimy, M. (1993). The book of Mirdad, New York, Arkana penguin books, 50.

2 Bhaqavad-qita olduğu kimi. (1991). Bhaktivedanta Buk Trast, 204.

${ }^{3}$ Naimy, M. (1993). The book of Mirdad, New York, Arkana penguin books, 51.

4 libid, 51.

5 İbid, 309.

6 İbid, 309.

7 İbid, 309.

8 ỉbid, 309.

${ }^{9}$ Bhaqavad-qita olduğu kimi. (1991). Bhaktivedanta Buk Trast, 33.

10 İbid, 131.
} 
the wise saved their lives from counter-effects of their deeds they did in the material world by help of serving Godloyally. ${ }^{1}$ For Vedas dedication of man to God is the most essential religiousprinciple.

\section{Conclusion}

In the final analysis, it is apparent that the plot basically covers the life of people around prophet Noah and what happened years after the Flood. The writer takes the advantage of the story in terms of writing his own thoughts up by means of the events and in the person of Mirdad he masterfully interprets the unity of God and man. What combines the ancient Indian beliefs with Mirdad is to overcome the untruthful ego and level up the pure consciousness. Herein, Mirdad serves for the moral progress of the mankind and purifying the cognizance of people. Supporting the idea of equality of people in the face of God, M.Naimy sought common traits between Prophet Muhammad and Prophet Jesus, as well as he benefited from the concepts of "I" and "God" in old Indian beliefs.

\section{References}

[1] Bhaqavad-qita olduğu kimi. (1991). Bhaktivedanta Buk Trast.

[2] İmanquliyeva, A. (2003). Yeni ərəb ədəbiyyatı korifeyləri, Bakı, Elm.

[3] Güngören, İ. (1981). Buda ve öğretisi, Ankara, Yol yayınları.

[4] Naimy, M. (1993). The book of Mirdad. New York, Arkana penguin books.

[5] Naimy, N. (1967). Mikhail Naimy, Beirut, Department of Apabic American University of Beirut.

[6] Hassan, Wail S. (2011). Immigrant Narratives. Orientalism and Cultural Translation in Arab American and Arab British Literature, New York, Oxford University Press.

[7] Гринцер, П.А. (1984). Классическая древноиндейская литература. История всемирной литературы, II т., М., Наука, 26-66.

\footnotetext{
${ }^{1}$ Bhaqavad-qita olduğu kimi. (1991). Bhaktivedanta Buk Trast, 135.
} 
